\title{
ANALISIS PENYALURAN PEMBIAYAAN ULTRA MIKRO BMT NUSA UMAT SEJAHTERA (NUS) CABANG BREBES BERDASAR AZAS MASLAHAH MURSALAH
}

\author{
Muhamad Naufal Khaerul Masi \\ Pascasarjana IAIN Syekh Nurjati Cirebon \\ Email : muhamednofal.11@gmail.com
}

\begin{abstract}
Issues that always surfaced classic among the small community that is the lowest layer (ultra micro) while being self-employed is about capital, access to financing from banks for their requirements can not be met (non bankable), This study aims to determine how the practices and mechanisms, as well as sound distribution of ultra micro financing, Bmt Nusa Umat Sejahtera (NUS) Brebes branch. to what extent contributes to the welfare of members through Ultra Micro Financing Distribution, BMT Nusa Umat Sejahtera (NUS) Brebes branch, know the Analysis of Ultra Micro Financing Distribution BMT Nusa Umat Sejahtera (NUS) Brebes branch, based on the principle of maslahah Mursalah Practices and governance of ultramicro financing distribution mechanisms in the Brebes branch of BMT Nu Sejahtera, using sharia-based contracts, ranging from mudhorobah, musyarokah and murobahah financing, all of which obscure the profit sharing system, and oppose the interest system (2) Contribution of the welfare of BMT Nusa Umat Sejahtera members from ultra-micro financing, that the purpose of utra micro financing is for the general public and members, especially for BMT Nusa Umat Sejahtera, are capital distributors, previously members of which have not received facilities from banking (3) Maslahah mursalah analysis of the distribution of microextracurricular financing in BMT Nusa Ummat Sejahtera, Brebes Branch, that all transactions use a sharia contract so that interest is avoided, which in the classification of maslahah mursalah safeguarding assets is classified as dharuriyat, and in its distribution, grouping and donation is carried out containing recitation as a forum for members to collaborate.
\end{abstract}

Keywords : Ultra Micro Financing, Maslahah Mursalah, BMT Nusa Ummat Sejahtera.

\begin{abstract}
Abstrak
Permasalahan-permasalahan klasik yang selalu mengemuka di kalangan masyarakat kecil yaitu lapisan terbawah (ultra mikro) tatkala hendak berwirausaha adalah tentang modal. mengakses pembiayaan dari perbankan karena adanya persyaratan yang tidak bisa dipenuhi (tidak bankable). Penelitian ini bertujuan untuk mengetahui bagaimana praktik dan mekanisme, serta tata kelolapenyaluran pembiayaan ultra mikro, BMT Nusa Umat Sejahtera (NUS) Cabang Brebes, sampai mana kontribusi kesejahteraan anggota melalui Penyaluran Pembiayaan Ultra Mikro BMT Nusa Umat Sejahtera (NUS) Cabang Brebes, mengetahui Analisis terhadap
\end{abstract}


Penyaluran Pembiayaan Ultra Mikro BMT Nusa Umat Sejahtera (NUS) Cabang Brebes berdasar asas maslahah Mursalah. (1) Praktik dan tata kelola mekanisme penyaluran pembiayaan ultra mikro di bmt nu sejahtera cabang brebes, menggunakan akad- akad yang berbasis syariah, mulai dari pembiayaan mudhorobah, musyarokah dan murobahah yang kesemuanya mengabut sistem bagi hasil, dan menentang sistem bunga (2) Kontribusi kesejahteraan anggota bmt nusa ummat sejahtera dari pembiayaan ultra mikro, bahwa tujuan pembiayan utra mikro adalah untuk masyarakat umumnya dan anggota khususnya bagi bmt nu sejahtera adalah penyalur modal, yang sebelumnya mereka anggota belum dapat fasilitas dari perbangkan (3) Analisis maslahah mursalah terhadap peyaluran pembiayaan uktra mikro di BMT Nusa Ummat Sejahtera Cabang Brebes, bahwa semua transaksi menggunakan akad yang syariah sehingga terhindar dari bunga, yang dalam klasifikasi maslahah mursalah menjaga harta adalah masuk dalam klasifikasi dharuriyat, dan dalam penyaluranya dilakukan pengelompokan dan pendanmpingan yang memuat pengajian sebagai wadah anggota untuk berjamiayah.

Kata Kunci : Pembiayaan Ultra Mikro, Maslahah Mursalah, BMT Nusa Ummat Sejahtera.

\section{Pendahuluan}

Pembiayaan Ultra Mikro (UMi) merupakan program tahap lanjutan dari program bantuan sosial menjadi kemandirian usaha yang menyasar usaha mikro yang berada di lapisan terbawah, yang belum bisa difasilitasi perbankan melalui program Pembiayaan Usaha Rakyat (KUR). UMi memberikan fasilitas pembiayaan maksimal Rp10 juta per nasabah dan disalurkan oleh Lembaga Keuangan Bukan Bank (LKBB). Pemerintah menunjuk Badan Layanan Umum (BLU) Pusat Investasi Pemerintah (PIP) sebagai coordinated fund pembiayaan UMi. Pembiayaan UMi disalurkan melalui LKBB.

Saat ini lembaga yang menyalurkan pembiayaan UMi antara lain: PT Pegadaian (Persero), PT Bahana Artha Ventura, serta PT Permodalan Nasional Madani (Persero). Sumber pendanaan berasal dari APBN, kontribusi pemerintah daerah dan lembagalembaga keuangan, baik domestik maupun global.Tahun 2018, UMi ditargetkan untuk menyentuh 800.000 pelaku usaha mikro yang tidak bankable.

Dalam penyalurannya, pembiayaan ultra mikro ada yang disalurkan secara langsung dan secara tidak langsung atau bekerja sama dengan lembaga linkage untuk menyalurkan pembiayaan UMi kepada anggota. PT. Pegadaian dan PT. Permodalan Nasional Madani menyalurkan pembiayaan UMi secara langsung kepada anggota. Sedangkan PT. Bahana Artha Ventura bekerja sama dengan beberapa koperasi untuk menyalurkannya kepada anggota. BMT Nusa Ummat Sejahtera menjadi salah satu dari 16 koperasi yang sudah menyalurkan pembiayaan UMi. Pada tahun 2018, BMT Nusa Ummat Sejahtera, sudah menerima Rp. 100 Miliar untuk menyalurkan pembiayaan Umi. 
ISSN cetak: $2654-5322$

\begin{tabular}{|l|}
\hline Kriteria \\
\hline Segmen Pasar \\
\hline Plafond Pembiayaan \\
\hline Profil End User \\
\hline Subsidi Pemerintah \\
\hline Cost Of Fund \\
\hline Pendampingan \\
\hline Penyalur \\
\hline Sumber Dana \\
\hline Jaminan \\
\hline Rate End User \\
\hline
\end{tabular}

Istimbat hukum

Kur
Mkiro, Kecil, Men
>Rp. 10.000.000
Individual Lendin
$10 \%$
$6 \%$
Tidak Ada
Bank (Executing D
Chaneling)
Masing-Masing B
Askrindo Dan Jam
End User
Subsidi
Total Rate (Riil)

Mursalah dalam pengembangan ekonomi syariah merupakan sebuah kewajiban, karena sejatinya maslahah mursalah merupakan inti dari semua bentuk praktik keuangan syariah, produk-produk ekonomi syariah dari berbagai jenis usaha yang kesemuanya menggunakan transaksi berbasis syariah merupakan suatu inovasi dalam rangka pengembangan ekonomi syariah, yang seluruhnya mengandung unsur Maslahah mursalah.

Implementasi penyaluran Pembiayaan Ultra Mikro ada beberapa parameter yang menjadi acuan Azas Maslahah al-Mursalah, dimana dalam praktiknya BMT Nusa Ummat Sejahtera, menerapkan sistem bagi hasil keuntungan dimana akad pembiayaannya menggunakan akad Musyarokah dan Murobahah, sehingga, bisa dikategorikan dalam Maslahah al-

\section{Mikro Dan Ultra Mikro}

Mikro, Terutama Ultra Mikro

$<$ Rp. 10.000.000

\begin{tabular}{|c|c|}
\hline $\begin{array}{l}\text { Group Len } \\
\text { Lending }\end{array}$ & ng Dan Individual \\
\hline $0 \%$ & \\
\hline $2 \%$ & \\
\hline Ada (Oleh & kkb, Pemda) \\
\hline Lkkb (Exec & ting) \\
\hline Pip Sebaga & Coodinated Fund \\
\hline Fiducia Piu & \\
\hline End User & $: 20 \%$ \\
\hline Subsidi & $: 0 \%$ \\
\hline Total Rate & $: 20 \%$ \\
\hline $\begin{array}{l}\text { Net Rate } \\
\text { Shu) }\end{array}$ & : 15\% (Setelah Dikurani \\
\hline
\end{tabular}

Mursalah Dharuriyat, dimana menjaga harta dari riba atau bunga pada pembiayaan konvensional,

Dalam

penelitian-penelitian sebelumnya yang relevan untuk penelitian belum ada yang menyinggung asas manfaat yaitu maslahah mursalah. Untuk itu peneliti akan mengaitkan penelitian tentang penyaluran pembiayaan untuk usaha mikro berdasar pada asas maslahah mursalah di mana peneliti akan melihat dari hukum manfaat. Yaitu, menetapkan hukum islam Untuk itu, dari uraian diatas penulis ingin meneliti bagaimana Penyaluran Pembiayaannya, implikasinya dan Analisis terhadap Penyaluran Pembiayaan Ultra Mikro Bmt Nusa Umat Sejahtera (NUS) Cabang Brebes berdasar asas maslahah Mursalah. Permasalahan inilah yang akan diangkat dalam judul tesis, dan penulis merasa tertarik meneliti dan mengkaji lebih 
dalam tentang hal-hal yang terkait dengan Pembiayaan produk Ultra Mikro (Umi) di Bmt Nusa Umat Sejahtera (NUS) Cabang Brebes yang akan dianalisis dalam Tesis yang berjudul "Analisis terhadap Penyaluran Pembiayaan Ultra Mikro Bmt Nusa Umat Sejahtera (NUS) Cabang Brebes berdasar asas maslahah Mursalah.

\section{Landasan Teori}

Pembiayaan Ultra Mikro (UMi) merupakan program tahap lanjutan dari program bantuan sosial menjadi kemandirian usaha yang menyasar usaha mikro yang berada di lapisan terbawah, yang belum bisa difasilitasi perbankan melalui program Pembiayaan Usaha Rakyat (KUR). UMi memberikan fasilitas pembiayaan maksimal Rp10 juta per nasabah dan disalurkan oleh Lembaga Keuangan Bukan Bank (LKBB). Pemerintah menunjuk Badan Layanan Umum (BLU) Pusat Investasi Pemerintah (PIP) sebagai coordinated fund pembiayaan UMi. Pembiayaan UMi disalurkan melalui LKBB. Saat ini lembaga yang menyalurkan pembiayaan UMi antara lain: PT Pegadaian (Persero), PT Bahana Artha Ventura, serta PT Permodalan Nasional Madani (Persero). Sumber pendanaan berasal dari APBN, kontribusi pemerintah daerah dan lembagalembaga keuangan, baik domestik maupun global.

Untuk memahami bagaimana penyaluran pembiayaan ultra mikro di BMT Nusa Ummat Sejahtera Cabang Breseb, maka terlebih dahulu harus dijelaskan secara umum mengenai pembiayaan, pembiayaan ultra mikro, BMT dan maslahah mursalah, guna melengkapi data yang dikaji.

1. Pembiayaan.

a. Definisi pembiayaan.

Pembiayaan secara luas berarti financing atau pembelanjaan, yaitu pendanaan yang dikeluarkan untuk mendukung investasi yang telah direncanakan, baik dilakukan sendiri maupun dijalankan oleh orang lain. Dalam arti sempit, pembiayaan dipakai untuk mendefinisikan pendanaan yang dilakukan oleh lembaga pembiayaan, seperti bank syariah kepada nasabah (Muhamad, 2002). Menurut M. Nur Rianto Al-Arif pembiayaan atau financing adalah pendanaan yang diberikan oleh suatu pihak kepada pihak lain untukmendukung investasi yang telah direncanakan, baik dilakukan sendirimaupun lembaga. Dengan kata lain pembiayaan adalah pendanaan yangdikeluarkan untuk mendukung investasi yang telah direncanakan (Al-Arif, 2012).

b. Tujuan Pembiayaan.

- Peningkatan ekonomi Artinya: masyarakat yang tidak dapat akses secara ekonomi, dengan adanya pembiayaan mereka dapat melakukan akses ekonomi.

- Tersedianya dana bagi peningkatan usaha Artinya: untuk pengembangan usaha membutuhkan dana tambahan. Dana tambahan ini dapat diperoleh melalui aktivitas pembiayaaan. Pihak yang surplus dana menyalurkan kepada pihakyang 
kekurangan dana, sehingga dapat digulirkan.

- Meningkatkan produktivitas, Artinya: adanya pembiayaan memberikan peluang bagi masyarakat agar mampu meningkatkan daya produksinya.

- Membuka lapangan kerja baru, Artinya: dengan dibukanya sectorsektor usaha melalui penmbahan dana pembiayaan, maka sector usaha tersebut akan menyerap tenaga kerja

- Terjadinya distribusi pendapatan, Artinya: masyarakat usaha produktif mampu melakuakan aktivitas kerja, berarti mereka akan memperoleh pendapatan dari hasil usahanya (Binti, 2012).

Sedangkan dengan pandangan mikro pembiayaan bertujuan untuk:

- Memaksimalkan laba, Artinya setiap usaha yang dibuka memiliki tujuan tertinggi, yaitu menghasilkan laba usaha. Setiap pengusaha berkeinginan untuk memperoleh laba maksimal. Dalam usaha mewujudkan usaha tersebut, maka mereka perludukungan dana yang cukup.

○ Meminimalkan resiko, Artinya usaha yang dilakukan bisa menghasilkan laba yang maksimal, maka salah satu unsurnya ialah dengan cara meminimalkan resiko yang mungkin timbul. Resiko kekurangan modal usaha dapat diperoleh dengan cara pembiayaan

- Pendayagunaan sumber ekonomi, Artinya sumber daya ekonomi dapat dikembangkan dengan melakukan mixing antara sumber daya alam dengan sumber daya manusianya ada, namun sumber daya modalnya tidak ada, maka dapat dipastikan diperlukan penambahan modal yaitu dengan cara pembiayaan.

- Penyaluran kelebihan dana, Artinya dalam kehidupan masyarakat ini ada pihak yang memiliki kelebihan sementara dan ada piak yang kekurangan. Dalam kaitannya dengan masalah dana, maka mekanisme pembiayaan dapat menjadi sarana penghubung dalam penyeimbangan dan penyaluran kelebihan dana dari pihak yang kelebihan (surplus) kepada pihak yang kekurangan (deficit) dana.

- Menghindari terjadinya dana menganggur, Dana yang masuk melalui berbagai rekening pada passive bank syariah, harus segera disalurkan dalam bentuk aktiva produktif. Sehingga terjadi keseimbangan antara dana yang masuk dan dana keluar Sumar'in (2012).

2. Maslahah al-Mursalah

Maslahah Mursalah sendiri Menurut bahasa, kata maslahah berasal dari Bahasa Arab dan telah dibakukan ke dalam Bahasa Indonesia menjadi kata maslahah, yang 
berarti mendatangkan kebaikan atau yang membawa kemanfaatan dan menolak kerusakan (Munawar, 1955). Menurut bahasa aslinya kata maslahah berasal dari kata salahu, yasluhu, salahan, يصلح , صالحا , حلحartinya sesuatu yang baik, patut, dan bermanfaat (Muhammad, 1973). Sedang kata mursalah artinya terlepas bebas, tidak terikat dengan dalil agama (al-Qur'an dan al-Hadits) yang membolehkan atau yang melarangnya (Munawar, 1955). Maslahahmursalah atau istislah sebagaimana disebutkan di atas,

Pertama kali diperkenalkan oleh Imam Malik (W. 97 H.), pendiri mazhab Maliki (Wael, 2000) Sedangkan Menurut AlGhazâli al maslah mursalah adalah

$$
\begin{aligned}
& \text { المصلحة بالإضافة إلى شهادة الثر عثانثانة } \\
& \text { أقسام : قسم شهد الثر ع لاتبار ها, وقسم شهد }
\end{aligned}
$$

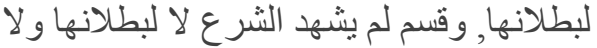

$$
\begin{aligned}
& \text { لاعتبار ها. } \\
& \text { أماما شهد الشرع لاعتبار ها فهي حجة, ويرجع } \\
& \text { حاصلها إلى القياس, وهو اقتباس الحكم من هن }
\end{aligned}
$$

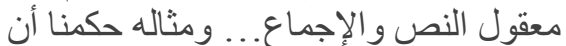

$$
\begin{aligned}
& \text { كل ما أسكر من مشروب الإحماع أومأكول فيحرم, قيسا } \\
& \text { على الخمر, لأنهاحرمت لحفظ من العقل الذي هو }
\end{aligned}
$$

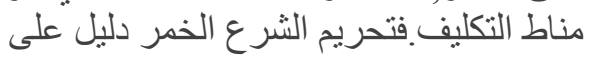

$$
\begin{aligned}
& \text { ملا حظة هذه المصلحة. } \\
& \text { القسم الثاني : ما شهد الثرع لا لبطلانها. }
\end{aligned}
$$

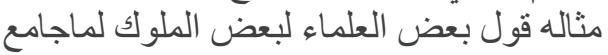

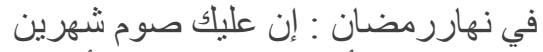

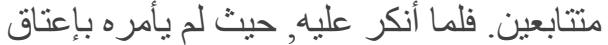

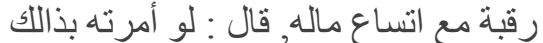

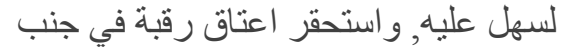

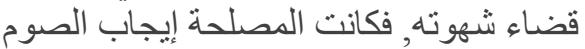

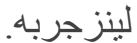

$$
\begin{aligned}
& \text { فهذا قول باطل, ومخالفة لنص الكتاب, } \\
& \text { بالمصلحة. وفتح هذا الباب يؤدي إلى تغيير }
\end{aligned}
$$

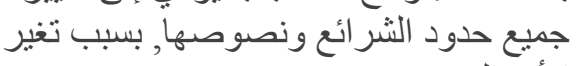

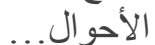

ISSN cetak: $2654-5322$

$$
\text { بالبطلان الثالث : مالم بشالا عتبار نص له معين الشر وهذا في }
$$

"Artinya

Maslahat dilihat dari segi dibenarkan dan tidaknya oleh dalil syara' terbagi menjadi tiga macam: maslahat yang dibenarkan oleh syara', maslahat yang dibatalkan oleh syara', dan maslahat yang tidak dibenarkan dan tidak pula dibatalkan oleh syara (tidak ada dalil khusus yang membenarkan atau membatalkannya).

Adapun maslahat yang dibenarkan oleh syara' maka ia dapat dijadikan hujjah dan kesimpulannya kembali kepada qiyas, yaitu mengambil hukum dari jiwa/semangat nash dan ijma. Contohnya kita menghukumi bahwa setiap minuman dan makanan yang memabukkan adalah haram diqiyaskan kepada khamar, karena khamar itu diharamkan untuk memelihara akal yang menjadi tempat bergantungnya (pembebanan) hukum. Hukum haram yang ditetapkan syara' terhadap khamar itu sebagai bukti diperhatikannya kemaslahatan ini.

Macam yang kedua adalah maslahat yang dibatalkan oleh syara'. Contohnya seperti pendapat sebagian ulama kepada salah seorang raja ketika melakukan hubungan suami istri di siang hari Ramadhan,hendaklah puasa dua bulan berturut-turut. Ketika pendapat itu disanggah, kenapa ia tidak memerintahkan raja itu untuk 
memerdekakan hamba sahaya, padahal ia kaya, ulama itu berkata, 'Kalau raja itu saya suruh memerdekakan hamba sahaya, sangatlah mudah baginya, dan ia dengan ringan akan memerdekakan hamba sahaya untuk memenuhi kebutuhan syahwatnya. Maka maslahatnya, wajib ia berpuasa dua bulan berturut-turut, agar ia jera. Ini adalah pendapat yang batal dan menyalahi Nash al-Kitab (dan hadispen.) dengan maslahat. Membuka pintu ini akan merobah semua ketentuan-ketentuan hukum Islam dan Nash-Nash-nya disebabkan perubahan kondisi dan situasi.

Macam yang ketiga adalah maslahat yang tidak dibenarkan dan tidak pula dibatalkan oleh syara (tidak ditemukan dalil khusus yang membenarkan atau membatalkannya). Yang ketiga inilah yang perlu didiskusikan (Inilah yang dikenal dengan maslahah mursalah)."

Kemudian menurut imam ghazali membagi maslhat menjadi tiga klaster,

$$
\begin{aligned}
& \text { أن المصلحة باعتبارقوتها في ذاتها تنقسم إلى الى } \\
& \text { ما هي في رنبة الضرور ات, و وإلى ما هي في إني } \\
& \text { رتبة الحاجات, و إلى ما يتعلق بالتحسينات } \\
& \text { و التزبينات, وتثقاعد أيضا عن رنبة الحاجات بالن }
\end{aligned}
$$

Artinya:

"Maslahat dilihat dari segi kekuatan substansinya ada yang berada pada tingkatan darurat (kebutuhan primer), ada yang berada pada tingkatan hajat (kebutuhan sekunder), dan ada pula yang berada pada posisi tahsinat dan tazyinat (pelengkap-penyempurna), yang tingkatannya berada di bawah hajat.

Abdul Wahab Khallaf, maslahah mursalah adalah maslahah di mana syari' tidak mensyari'atkan hukum untuk mewujudkan maslahah, juga tidak terdapat dalil yang menunjukkan atas pengakuannya atau pembatalannya (Abdullah, 2002). Maslahah mursalah sebagai metode hukum yang mempertimbangkan adanya kemanfaatan yang mempunyai akses secara umum dan kepentingan tidak terbatas, tidak terikat. Dengan kata lain maslahah mursalah merupakan kepentingan yang diputuskan bebas, namun tetap terikat pada konsep syari'ah yang mendasar. Karena syari'ah sendiri ditunjuk untuk memberikan kemanfaatan kepada masyarakat secara umum dan berfungsi untuk memberikan kemanfaatan dan mencegah kemazdaratan (kerusakan).

3. BMT

a. Pengertian BMT

Baitul Mal wa Tamwil merupakan lembaga ekonomi atau keuangan Syari'ah non perbankan yang sifatnya informal. Lembaga yang didirikan oleh Kelompok Swadaya Masyarakat (KSM) yang berbeda dengan lembaga keuangan perbankan dan lembaga keuangan formal lainnya sehingga BMT disebut bersifat informal. Selain berfungsi sebagai lembaga keuangan, BMT juga berfungsi sebagai lembaga ekonomi (BT). Selain BMT bertugas menghimpun dana dari masyarakat dan menyalurkan dana kepada masyarakat.BMT berhak melakukan kegiatan ekonomi, seperti 
perdagangan,industry dan pertanian (Djazuli \& Yadi, 2002).

Menurut Abdul Aziz dan Mariyah Ulfah Baitul Mal wa Tamwil (BMT) adalah lembaga keuangan mikro yang dioperasikan dengan prinsip bagi hasil, menumbuh kembangkan bisnis usaha mikro dan kecil dalam rangka mengangkat derajat dan martabat serta membela kepentingan kaum fakir miskinBaitu Mal Wal Tamwil adalah lembaga keuangan nonbank yang beroperasi berdasarkan syariah dengan prinsip bagi hasil, yang didirikan oleh dan untuk masyarakat di suatu tempat atau daerah (Azra, 2003), Sedangkan Menurut Karnaen A. Perwataatmadja, Baitul Mal wal Tamwil merupakan pengembangan ekonomi berbasis masjid sebagai sarana untuk memakmurkan masjid (Karnaen, 2002).

Jadi, Baitul Mal wa Tamwil adalah balai usaha mandiri terpandu yang isinya berintikan bayt al-mal wa altamwil dengan kegiatan mengembangkan usaha-usaha produktif dan investasi dalam meningkatkan kualitas kegiatan eonomi pengusaha kecil bawah dan kecil dengan antara lain mendorong kegiatan menabung dan menunjang pembiayaan kegiatan ekonominya.

BMT memiliki dua bidang kerja yaitu sebagai Lembaga Mal ( Baitul Mal) dan sebagai lembaga Tamwil ( Baitul Tamwil). Baitul Mal yang dimaksud adalah untuk menghimpun zakat dan infak maupun sedekah dan menyalurkan kepada pihakpihak yang berhak dalam bentuk pemberian tunai maupun pinjaman modal tanpa bagi hasil, yang mana Baitul Mal bersifat nirlaba (sosial).

Sedangkan Baitut Mal artinya menghimpun dana masyarakat yang mampu dalam bentuk saham, simpanan atau deposito dan menyalurkannya sebagai modal usaha dengan ketentuan bagi hasil antara pemodal dan peminjam dan BMT. BMT mengembangkan usaha- usaha produktif dan investasi dalam meningkatkan kualitas kegiatan ekonomi pengusaha makro dan mikro dengan antara lain mendorong kegiatan menabung dan menunjang pembiayaan kegiatan ekonominya. BMT menggunakan badan hukum koperasi dan sering disebut dengan koperasi jasa keuangan syariah ( KJKS).

\section{Metode Penelitian.}

Metode analisis data dalam penelitian ini penulis menggunakan metode deskriftif kualitatif. Deskriftif yaitu berusaha menggambarkan, menganalisa, dan menilai materi yang menjadi fokus penelitian. Adapun data yang dianalisis adalah data yang dikumpulkan dari berbagai sumber data, baik primer maupun data sekunder, yaitu dari hasil wawancara, catatan lapangan, dokumen resmi, file-file dan web terkait masalah yang penyusun bahas. Materi tersebut berupa Penyaluran pembiayaan Ultra Mikro. Metode ini digunakan untuk memahami materi yang terkait Penyaluran pembiayaan Ultra mikro di BMT NUS Cab. Brebes.

Sumber data yang digunakan dalam penelitian ini terbagi kedalam dua kategori, yaitu :

a. Sumber Primer 
Sumber Primer adalah sumber data yang langsung dikumpulkan oleh peneliti dari sumber pertamanya yang diperoleh langsung melalui wawancara kepada pengelola BMT Nusa Umat Sejahtera cabang Brebes dan pelaku usaha Ultra Mikro yang melakukan pembiayaan, observasi tentang Penyaluran Pembiayaan Ultra Mikro BMT Nusa Utama Sejahtera Cabang Brebes.

b. Sumber Sekunder

Sumber Sekunder yaitu sumber yang biasanya telah tersusun dalam bentuk dokumen-dokumen. Biasanya data yang diperoleh dari buku-buku dan dokumentasi yang relevan dengan penelitian ini. Data ini biasanya digunakan untuk melengkapi data primer, dalam hal ini buku-buku yang berkaitan dengan penyaluran Pembiayaan Ultra mikro bagi usaha-usaha Mikro.

Tekhnik pengambilan Data Dalam hal ini, penulis melakukan penelitian di BMT Nusa Umat Sejahtera (NUS) Cabang Brebes untuk memperoleh data-data yang diperlukan, penulis menggunakan teknik sebagai berikut:

a. Metode Interview (Wawancara)

Wawancara yaitu proses komunikasi dengan cara bertanya secara langsung untuk mendapatkan informasi atau keterangan dari informan (Nasution, 1993). Wawancara adalah pewawancara yang mengajukan sejumlah pertanyaan yang telah disusun dan terwawancara yang memberi jawaban atas pertanyaan, untuk diajukan kepada responden atau informan guna mendapatkan data atau keterangan tertentu yang diperlukan dari suatu penelitian (Moleong, 2009). Metode wawancara ini dilakukan kepada Manager PJs Penyaluran Pembiayaan Ultra Mikro di BMT NUS Cabang Brebes dan para anggota usaha mikro penerima Pembiayaan Mikro dari BMT NUS Cabang Brebes. Berhubung dengan kondisi Pandemi Covid19 yang mengharuskan physical distancing maka peneliti akan mewancarai lewat online atau bertemu dengan protokol kesehatan yang ketat guna mencegah penularan COVID-19.

b. Metode Observasi

Metode Observasi adalah suatu proses yang kompleks dan tersusun rapi dari berbagai proses biologis maupun psikologis (Sugiono, 2013). Bukan hanya metode pengamatan dan pencatatan tetapi juga harus memahami, menganalisa, dan mengadakan pencatatan yang sistematis. Mengamati adalah menatap kejadian gerak atau proses yang harus dilaksanakan secara objektif (Arikunto, 2002). Metode ini digunakan untuk mengamati proses Penyaluran Pembiayaan Ultra Mikro sampai ke tangan penerimanya yaitu pelaku usaha mikro berikut pendampingan yang akan di evaluasi berdasar asas maslahal mursalah.

c. Metode Dokumentasi

Metode Dokumentasi adalah pengumpulan data kualitatif dengan melihat atau menganalisis dokumendokumen yang dibuat oleh objek sendiri atau oleh orang lain tentang subjek. Dan mengumpulkan bukti-bukti atau keterangan-keterangan seperti kutipankutipan dari surat kabar, gambar-gambar, dan sebagainya. Pengumpulan dokumentasi 
dikondisikan dengan keadaan. Jika pandemi Covid 19 belum berakhir, peneliti akan melakukan lewat media Daring.

\section{Pembahasan}

\section{Praktik dan Mekanisme Penyaluran Pembiayaan. Ultra}

Praktik dan Mekanisme Penyaluran Pembiayaan. Ultra Mikro di BMT NU Sejahtera cabang Brebes, yakni sama dengan produk pembiayaan yang lain yang ada di BMT NU Sejahtera cabang Brebes, yaitu pembiayaan berupa Musyarokah, dan Mudhorobah, yang menganut sistem bagi hasil, dan yang menjadi faktor pembeda dari pembiayaan Ultra Mikro adalah sumber Pembiayaan. Dimana pembiayaan Umum berasal dari BMT NU Sejahtera itu sendiri, sedangkan pembiayaan Ultra mikro dari kementiran Keuangan yang Menunjuk PT. Bahana Artha Ventura, sebagai penyalur pembiayaan ultra mikro, kemudian disalurkan melalui BMT NU Sejahtera dengan Pola linkage, dan sebagai pemutus langsung kepada end user atau anggota. Pembiayaan Ultra Mikro di BMT NU Sejahtera cabang Brebes, antara lain:

\section{Mudhorobah,}

Merupakan pola pembiayaan dimana BMT NU Sejahtera cabang Brebes, sebagai posisi shohibul mall, kepada mudharib atau anggota untuk melakukan usaha (bisnis) tanpa ditentukan jenis usahanya, tempatnya, waktunya, sifat bisnisnya, dan/atau pihak yang melakukan usahanya. Dalam prakteknya pembiayaan mudharabah dilakukan oleh dua pihak, dimana pihak KSPPS sebagi pihak pertama sebagai pemilik modal (Shahibul Mal) dan pihak kedua sebagai pengelola modal (mudharib). Awalnya dalam proses penandatanganan perjanjian KSPPS BMTNU Sejahtera menjelaskan secara terperinci biaya-biaya apa saja yang dikeluarkan oleh KSPP BMT NU Sejahtera.

Adapun mekanisme dalam pembiayaan mudharabah pada KSPPS BMT NU Sejahtera Cabang Brebes adalah sebagai berikut:

a. Calon anggota atau nasabah yang ingin mengajukan pembiyaan datang langsung ke kantor KSPPS BMT NU Sejahtera untuk mendapatkan informasi pembiayaan atau bagian marketing mendatangi langsung ke anggota yang ingin mengajukan pembiayaan.

b. Membawa persyaratan yang harus dipenuhi oleh nasabah/ anggota untuk mendapatkan pembiayaan.

c. Bagian marketing melakukan survei atau penilaian terhadap pengajuan pembiyaan ke nasabah.

d. Setelah pengajuan pembiayaan masuk pihak KSPPS BMT NU Sejahtera melakukan penilaian ulang terhadap berkas yang masuk. Jika permohonan pengajuan pembiayaan diterima melalui keputusan komite pembiayaan, maka selanjutnya pihak KSPPS BMT NU Sejahtera memberikan informasi kepada calon nasabah bahwa permohonan pembiayaan disetujui dan selanjutnya dijadwalkan untuk akad.

e. Dalam proses akad ini terjadi tawar menawar antara KSPPS BMT dan 
anggota/nasabah untuk pembagian penentuan margin bagi hasil, akan tetapi di KSPPS BMT NU Sejahtera sudah ada prosedur sendiri untuk perolehan margin bagi hasil tersebut. Adapun untuk anggota yang pertama kali melakukan pembiayaan tidak boleh menawar seberapa besar bagi hasil yang diinginkan, anggota harus mengikuti aturan yang sudah menjadi ketetapan BMT. Tetapi setelah pembiayaan kedua nasabah/ anggota boleh melakukan tawar menawar jika margin bagi hasil yang diberikan pihak BMT terlalu besar. Setelah terjadi kesepakatan antara kedua belah pihak untuk penentuan besarnya bagi hasil, maka proses selanjutnya selanjutnya adalah.

f. Penandatanganan kontrak, apa saja yang menjadi hak dan kewajiban nasabah. Setelah selesai tandatangan kontrak selanjutya adalah.

g. Pencairan pembiayaan. Dana yang dicairkan sudah termasuk potongan biaya administrasi.

- Mengisi formulir pembiayaan

- Foto copy KTP suami dan isteri

- Foto copy Kartu Keluarga

- Foto copy Buku Nikah (bagi yang sudah menikah)

- Foto copy jaminan (warkah, BPKB disertai STNK. Sertifikat tanah disertai SPPT. Jika barang jaminan atas nama orang lain harus dilengkapi dengan surat kuasa dari pemegang hak

- Foto copy Legalitas ( bagi badan usaha)
- Bersedia menandatangani suratsurat terkait dengan pembiayaan

- Bersedia membayar biaya yang dikeluarkan untuk proses pembiayaan.

Apabila nasabah telat membayar 12 bulan dikenakan SP 1, apabila dalam waktu seminggu belum melunasi juga maka akan di kenakan SP 2, apabila telat lagi akan dikenakan SP 3, dan apabila sudah tidak bisa di bicarakan baik-baik maka akan di lakukan tarik jaminan. Jaminan akan ditarik oleh BMT dan akan dijual yang nantinya akan di gunakan untuk melunasi hutang nasabah, dan apabila uang dari hasil penjualan lebih setelah dikurangi seluruh hutang dan denda maka akan dikembalikan kepada nasabah. Denda yang ditetapkan oleh BMT kepada nasabah yang menunggak akan dikenakan denda $0.25 \% \mathrm{X}$ angsuran $\mathrm{X}$ perhari.

2. Murobahah.

Praktek pembiayaan murabahah di BMT NU Sejahtera adalah dalam metode penentuan harga jual murabahah di BMT NU Sejahtera yang menggunkan metode keuntungan flat dimana perhitungan markup atau margin terhadap nilai harga pokok pembiayaan secara tetap dari satu periode ke periode lainnya, walaupun baki debetnya menurun sebagai akibat dari adanya angsuran harga pokok. Penentuan margin atau keuntungan di BMT NU Sejahtera ditentukan dalam bentuk persentase, dimana margin yang ditentukan sampai 
$1,5 \%$ per bulan untuk jangka waktu pembiayaan sampai dengan 4 tahun.

Penentuan harga jual beli murabahah pada BMT NU Sejahtera K.C. Brebes paradigma yang dimiliki masih menggunakan prinsip-prinsip sama dengan paradigma yang ada pada bank konvensional, diantaranya:

a. Penetapan margin/keuntungan yang dilakukan oleh BMT NU Sejahtera masih mengunakan fixed rate dengan metode flate rate dimana penetapan margin dan hutang pokok yang dibebankan setiap bulan adalah sama sehingga pembayaran total cicilan setiap bulan besarnya tetap sampai selesai.

b. Penetapan harga jual murabahah pada BMT NU Sejahtera memberikan beban keuntungan yang harus diberikan untuk pemegang saham dan dana pihak ketiga kepada nasabah pembiayaannya. Dimana operasional BMT NU Sejahtera lebih dominan bertumpu pada selisih keuntungan.

c. Penetapan margin yang dilakukan BMT NU Sejahtera masih tergantung pada kebutuhan untuk memperoleh keuntungan riil sehingga dapat memberikan beban keuntungan yang harus diberikan kepada dana pihak ketiga dan pemegang saham.

Perhitungan keuntungan dengan cara sistem flate rate, dengan sistem anuitas yang dipergunakan oleh bank untuk menghitung bunga kreditnya saat ini merupakan teknik matematik dan teknik ini digunakan dalam menghitung keuntungan murabahah. Namun demikian, menurut penulis, penentuan harga jual produkproduk BMT harus tetap memperhatikan ketentuan-ketentuan yang dibenarkan menurut Syari'ah. Oleh karena itu BMT perlu menetapkan metode yang tepat dan efisien agar kemasan produk murabahah dapat memberikan keuntungan secara adil antara pihak BMT dengan nasabah pembiayaan murabahah.

\section{Musyarokah.}

Praktek pembiayaan musyarokah di BMT NU Sejahtera adalah dalam metode penentuan harga jual murabahah di BMT NU Sejahtera Pembiayaan musyarakah adalah akad kerjasama yang terjadi diantara para pemilik dana untuk menggabungkan modal, melalui usaha bersama dan pengelolaan bersama dalam suatu hubungan kemitraan Bagi hasil ditentukan sesuai dengan kesepakatan (biasanya ditentukan berdasarkan jumlah modal yang diberikan dan peran serta masing-masing pihak (Saeed, 2003).

Ascarya dalam buku yang berjudul Akad dan Produk Bank Syariah mengatakan musyarakah merupakan akad bagi hasil ketika dua atau lebih pengusaha pemilik dana/modal bekerja sama sebagai mitra usaha membiayai investasi usaha baru atau yang sudah berjalan. Mitra usaha pemilik modal berhak ikut serta dalam menejemen perusahaan, tetapi itu tidak merupakan keharusan. Para pihak dapat membagi pekerjaan mengelola usaha sesuai kesepakatan dan mereka juga dapat meminta gaji/upah untuk tenaga dan 
keahlian yang mereka curahkan untuk usaha tertentu (Ascarya, 2012).

Penekanan praktek Pembiayaan pola Musyarokah. Adalah kepada para petani pekebun dan nelayan, dimana pada profesi tersebut, memiliki penghasilan yang terikat dengan waktu, dimana penghasilan didapat dari hasil panen dan penyelesaian pekerjaan yang lebih dari satu bulan. Dan pada praktiknya pembiayaan bagi hasil dibebankan setiap bulan, sedangkan pokok hutang ditanggung diakhir ketika tenor perjanjian kontrak musyarokah berakhir.

Perjanjian musyarokah BMT NU Sejahtera, memberikan tengat waktu khusus bagi pembiayaan musyarokah yaitu tenoryaitu:

a. 1 (satu bulan) dimana pengembalian bagi hasil dan pokok hutang berakhir dalam waktu satu bulan.

b. 3 (tiga bulan) dimana pengembalian bagi hasil selama tiga bulan, dan pokok hutang dikembalikan pada bulan ke tiga

c. 6 (enam bulan0 dimana pengembalian bagi hasil dilakukan setiap bulan selama enam bulan dan pokok hutang berakhir dalam bulan ke 6

d. 12 (satu tahun) dimana pengembalian bagi hasil dilakukan selama dua belas bulan, dan pengembalian hutang pokok pada bulan ke dua belas,

1) Kontribusi Kesejahteraan Anggota BMT NU Sejahtera

kesejahteraan adalah suatu tata kehidupan dan penghidupan sosial materil maupun sprituil yang diliputi oleh rasa keselamatan, kesusilaan dan ketentraman lahir batin, Menurut BPS (Badan Pusat Statistik) pendapatan adalah seluruh penghasilan yang diterima baik sektor formal maupun non formal yang terhitung dalam jangka waktu tertentu. Pendapatan merupakan jumlah barang dan jasa yang memenuhi tingkat hidup masyarakat, dimana dengan adanya pendapatan yang dimiliki oleh setiap jiwa disebut dengan pendapatan perkapita dimana pendapatan perkapita menjadi tolok ukur kemajuan atau perkembangan ekonomi (Prakoso, 2013).

Pada pembiayaan ultra mikro di bmt yang dimaksud dengan penambahan pendapatan yaitu. pertama mendapatkan modal pembiayaan karna memang pembiayaan Ultra Mikro ditujukan kepada anggota yang belum bisa mendapatkan fasilitas pembiayaan dari bank atau pemerintah di bidang usaha mikro, kecil, dan menengah yang tercatat dalam SIKP (Permenkeu, 2018). Karna memang pembiayaan ultra mikro ditujukan kepada anggota yang tidak bankkable dan tata pelaksanayanya di BMT Nusa Ummat Sejahtera memiliki sistem silk Ultra mikro dimana dalam sistem tersebut BMT bisa meninjau setiap Nomor Induk Kependudukan, dan dapat diketahui bahwa Nama atas NIK tidak memiliki fasilitas pembiayaan, sehingga bisa tepat sasaran.

Kedua adanya penambahan omzet dan penambahan pemasukan dari anggota, dimana di BMT Nussa Ummat Sejahtera memiliki program simpanan wajib dan wadiah bagi anggota, juga merupakan alat untuk mengukur penambahan pendapatan dan penarikan angsuran dari anggota. Dimana rata-rata jumlah saldo pada tabungan di wadiah selalu terisi, dan lebih dari jumlah untuk angsuran pembiayaan. 
Ketiga adanya penambahan relasi usaha, dimana di BMT Nusa Ummat Sejahtera ada pengelompokan anggota berdasar dari profesi, menjadi dua kelompok yaitu pedagang dan petani, karna hampir rata-rata anggota BMT Nusa Ummat Sejahtera adalah pedagang dan petani dan usaha yang tidak jauh pedagang dan petani, dari petani memiliki wadah kelompok tani cinta tani, dimana didalamnya terdapat ketua kelompok yang merupakan pemilik toko obat pertanian dan anggotanya merupakan para petani yang tergabung dalam anggota BMT Nusa Ummat Sejahtera, dengan tujuan untuk mempermudah proses pemenuhan kebutuhan usaha masing-masing anggota. Begitu juga dengan anggota BMT Nusa Ummat Sejahtera yang berprofesi sebagai pedagang, ada kelompok pedagang Kang Santri, dimana didalamanya terdapat ketua kelompok yang merupakan pemilik toko grosir, dan anggotanya adalah para pedagang yang lebih kecil dimana dengan adanya kelompok ini bisa dengan mudah memenuhi kebutuhan usaha dari masingmasing anggotanya, sehingga lebih mudah dalam akses pemenuhan usahanya.

Produk funding di BMT yang merupakan koperasi syariah adalah wadiah, dimana simpanan dari anggota secara umum dan simpanan wajib dan pokok bagi anggota yang memiliki angsuran, yang pada proses pendampinganya, semua anggota diwajibkan menabung, tujuanya adalah untuk memberikan kenyamanan bagi anggota baik yang melakukan pembiayaan yaitu untuk mendidik dan mendampingi usaha sebagi alat kontrol aktifa lancar anggota dan mengetahui keadaan ekonomi anggota.

Pembiayaan Ultra Mikro yang diberikan oleh lembaga keuangan bertujuan untuk membantu masyarakat dalam memenuhi kebutuhan dalam meningkatkan usahanya. Masyarakat, pengusaha, lembaga, badan usaha, dan lain-lain yang membutuhkan dana. Salah satu produk yang disalurkan oleh lembaga keuangan syariah adalah Pembiayaan ultra mikro syariah (At tamwil li al hajah al muntahyat as-shugra). Pembiayaan Ultra Mikro Syariah adalah Pembiayaan yang diberikan oleh Lembaga Keuangan Syariah kepada nasabah yang membutuhkan Sekumpulan barang dan/atau Jasa yang nilainya sangat kecil (Ultra Mikro) dan beragam jenisnya.

Akad yang boleh digunakan pada Pembiayaan Ultra Mikro Syariah Berdasarkan Fatwa Dewan Syariah Nasional No. 119/DSN-MUI/II/2018 Adalah dengan menggunakan akad Jual Beli, Akad Jual Beli Murobahah, Akad Jual Beli Salam, Akad Jual Beli Istishna, Akad Ijarah, atau Akad Ijarah Muntahiyya Bittamlik (Fatwa, 2018) Dimana akad tersebut merupakan akad menggunakan sistem bagi hasil, yang menerapkan pembagian untung dan rugi bersama tapi dengan patokan yang disepakati, sehingga terhindar dari sistem bunga yang dinyatakan haram oleh Majelis Ulama Indonesia, sehingga anggota bisa menjaga hartanya dari suatu transakri yang diharamkan (Fatwa, 2004).

\section{Penutup}

Kesimpulan, 
Dari hasil penelitian yang telah dilaksanakan, dapat diambil kesimpulan sebagai berikut:

1. Praktik dan tata kelola mekanisme penyaluran pembiayaan ultra mikro di bmt nu sejahtera cabang brebes, menggunakan akad- akad yang berbasis syariah, mulai dari pembiayaan mudhorobah, musyarokah dan murobahah yang kesemuanya mengabut sistem bagi hasil, dan menentang sistem bunga yang menurut sebagian fatwa ulama diharamkan termasuk fatwa Majelis Ulama indonesia.

2. Kontribusi kesejahteraan anggota bmt nusa ummat sejahtera dari pembiayaan ultra mikro, bahwa tujuan pembiayan utra mikro adalah untuk masyarakat umumnya dan anggota khususnya bagi bmt nu sejahtera adalah penyalur modal, yang sebelumnya mereka anggota belum dapat fasilitas dari perbangkan karena masuk dalam klasifikasi tidak bankable, sekarang bisa mengakses produk pembiayaan ultra mikro, sebagai bahan permodalan awal, yang kedua bahwa diwajibkanya BMT Nusa Ummat Sejahtera mendampingi anggota yang mengambil pembiayaan ultra mikro, maka ada pembinaan arahan dan motivasi serta pembentukan kelompok usaha untuk mempermudah akses usaha anggota sehingga berimbas pada kenaikan kesejahteraan anggota.

3. Analisis maslahah mursalah terhadap peyaluran pembiayaan uktra mikro di
BMT Nusa Ummat Sejahtera Cabang Brebes, bahwa semua transaksi menggunakan akad yang syariah, sehingga terhindar dari bunga, yang dalam klasifikasi maslahah mursalah menjaga harta adalah masuk dalam klasifikasi dharuriyat, dan dalam penyaluranya dilakukan pengelompokan dan pendanmpingan yang memuat pengajian sebagai wadah anggota untuk berjamiayah yang mana program tersebut mendatangkan maslahah yang dalam kategorinya bisa masuk dalam maslhah tahsiniayat.

Saran

1. Penelitian ini diharapkan dapat menjadi tambahan ilmu pengetahuan dan pengembangan-pengembangan ilmu di bidang ekonomi terutama hal-hal yang berhubungan dengan faktor-faktor yang berhubungan dengan pembiayaan ultra mikro, di koperasi syariah,

2. Penelitian ini menggunakan pendekatan metode kualitatif, dimana analisis deskriptif lebih condong untuk penjabaran penelitian. Penelitian lebih lanjut dimana perhitungan numeric menjadi dasar pengambilan keputusan.

\section{Daftar Pustaka}

Abdullah Saeed. (2003) Bank Islam Dan Bunga. Yogyakarta:Pustaka Pelajar.

Abdullah Wahab Khalla. (2002). Ilmu Ushulul Fiqh. terj. Noer Iskandar alBansan. Kaidah-kaidah Hukum Islam, Jakarta: PT. Raja Grafindo Persada, Cet-8,

A.Djazuli dan Yadi Yanwari. (2002). Lembaga-Lembaga Perekonomi Umat 
Sebuah Pengenalan. Jakarta: Rajawali Press.

Ascarya. (2012). Bank dan Produk Bank Syariah. Jakarta: Rajawali Press.

Azyumardi Azra. (2003). Berdema Untuk Semua. Jakarta:PT.Mizan Publika.

Binti Nur Aisiyah (2015). Manajemen Pembiayaan Bank Syariah. Yogyakarta:Kalimedia.

Fatwa DSN-MUI NO 119/DSN-

MUI/II/2018

\section{FATWA MAJELIS ULAMA}

INDONESIA Nomor 1 Tahun 2004

Tentang BUNGA

(INTEREST/FA'IDAH)

Jati Prakoso. (2013). Peranan Tenaga Kerja Modal dan Teknologi terhadap Peningkatan Pendapatan Mayarakat di Desa Asem Doyong Kecamatan Tanam Kabup aten Pemalang . (Skripsi--Universitas Negeri Semarang. Jawa Tengah).

Karnaen A. Perwataatmadja. (2002). Membumikan Ekonomi Islam Di Indonesia. Depok:Usaha kami.

Lexy J. Moleong. (2009). Metodologi Penelitian Kualitatif, (Bandung: Pt. Remaja Rosdakarya, Cet. 26).

M. Farid Nasution. (1993). Penelitian

Praktis, Medan: Iain Press

M. Nur Rianto Al-Arif. (2012). DasarDasar Pemasaran Bank Syariah. Bandung: Alfabeta.

Muhamad. (2002). Manajemen Bank Syariah. Yogyakarta: UPP AMP YKPN.
Muhammad Yunus. (1973). Kamus Arab Indonesia, Jakarta: Yayasan Penyelenggaraan Penerjemah dan Penafsir al-Qur'an,

Munawar Kholil. (1955). Kembali Kepada al-Quran dan as-Sunnah. Semarang: Bulan Bintang,

Peraturan menteri Keuangan republik indonesia nomor 95 /pmk.05/2018 tent ang pembiayaan ultra mikro

PINBUK(t.t), Pedoman Cara Pembentuk BMT Balai Usaha Mandiri Terpandu. PINBUK,Jakarta

Suharsimi Arikunto. (2002). Prosedur Penelitian Suatu Pendekatan Praktek, Jakarta: PT. Rineka Cipta)

Sugiono.(2013).Metode Penelitian Kombinasi. Bandung: Alfabeta.

Sumar'in. (2012). Konsep Kelembagaan Bank Syariah. Yogyakarta: Graha Ilmu.

Wael B. Hallag. (2000). A History of Islamic Legal Theories, Alih bahasa E. Kusnadiningrat, Rajawali Press, Jakarta,

Wawancara dengan Bapak H. Surahman

S.E., Koordinator Area BMT NU

Sejahtera Pusat Semarang.

Wawanca dengan Siti Kamilah (admin BMT NU Sejahtera KC. Brebes). 